\title{
A DEATH GREATLY EXAGGERATED: ROBIN G. COLLINGWOOD AND THE "ROMANISATION" OF ROMAN BRITAIN
}

Renato Pinto ${ }^{1}$

\begin{abstract}
Robin G. Collingwood is considered the great researcher of RomanoBritish studies in the interbellum period. His contributions in this field, although less famous than his works in the Philosophy of History, succeeded in inserting Roman Britain into British history, and brought in tow a unique interpretative approach that weaves philosophical and historical concepts with his archaeological research on the phenomenon of the "Romanisation" of the Roman provinces. His belief in the inevitability of the scholar's prejudice in approaching his object and in his/her need and possibility to recreate the past in his/her own mind, in the present, has given Collingwood a kind of bibliographic renaissance in post-processual archaeological production. Somehow connected to this, his conception of "Romanisation," however rigid, is indelible to the epistemological critique of the term in British postcolonialism. Collingwood's legacy usually oscillates between the reverential and the ridiculous, something that only reinforces the importance of such longlived movements.
\end{abstract}

\section{Keywords}

Robin G. Collingwood; Roman Britain; Romanisation.

${ }^{1}$ Assistant Professor, Federal University of Pernambuco, Recife, Brazil. E-mail: tdhm@uol.com.br 


\section{Resumo}

Robin G. Collingwood é considerado o grande pesquisador dos estudos romano-bretões no período entreguerras. Suas contribuições neste campo, ainda que menos famosas do que seus trabalhos na Filosofia da História, lograram inserir a Bretanha Romana na história Britânica, e trouxeram, a reboque, uma abordagem interpretativa única que alinhavava conceitos filosóficos e históricos às suas pesquisas arqueológicas sobre o fenômeno da "Romanização" das províncias romanas. Sua crença na inevitabilidade do preconceito do estudioso ao se aproximar de seu objeto e na necessidade e possibilidade deste de recriar o passado em sua mente, no presente, rendeu-lhe uma espécie de renascença bibliográfica na produção arqueológica pós-processual. De alguma forma conectada a isso, sua concepção da "Romanização", ainda que rígida, mostra-se indelével à crítica epistemológica do termo no pós-colonialismo britânico. O legado de Robin Collingwood costuma oscilar entre o reverencial e o ridículo, algo que só reforça a importância de tais movimentos tão longevos.

\section{Palavras-chave}

Robin G. Collingwood; Bretanha Romana; Romanização. 


\section{Introduction}

I was first introduced to the studies about Roman Britain and its "Romanisation" (being a polemical term, it is presented in quotation marks here) by Pedro Paulo Funari, at the end of the 1990s. But his works about the presence of the Baetica amphorae in Vindolanda go back to the beginning of the decade (Funari, 1991). Later, he published an important and influent study about the Roman Britain in Revista de História da Arte e Arqueologia (1994). His researches and publications about the Roman province remain relevant and innovative. My masters and doctorate degree, which deal with themes directly connected to Roman Britain's "Romanisation" discourses, were results of his pioneering, inspirational, and valuable supervision. This small paper that presents some brief reflections on the Romano-British research developed by Robin Collingwood in the first half of the 20th century has the main purpose of honouring the great researcher and Professor Pedro Paulo Funari is. I hope it can also function as an introduction to the epistemology of Roman Britain's "Romanisation".

\section{R. G. Collingwood}

Robin George Collingwood (1889 - 1943), philosopher, historian and English archaeologist, became the most famous scholar in his family, already involved with Arts, History and Archeology departments before him. R. G. Collingwood was educated at Rugby School and became a Professor at Oxford University. He was, and still is, considered by many an idealist, although he has never accepted this label. In fact, at the beginning of his academic career, at least until 1916, Collingwood was grouped alongside self-titled realistic scholars, especially E. F. Carritt and John Cook Wilson. Progressively, he started to move away from realism and to approach idealism exponents of European Philosophy, such as Benedetto Croce. His greatest influences, besides Haverfield, were his dad, William G. Collingwood, Kant, Ruskin and idealist Italian authors like Croce and Gentile. Collingwood would translate many other works of both Croce and Giovanni Gentile. His works in Art and Esthetics also stood out at the time (Ridley, 2001). However, it was in the fields of Philosophy and History, and in the defense of the approximation of these two subjects, that Collingwood most succeeded. Collingwood was the only student of Francis J. Haverfield (discussed below) who survived the First World War, where he served in the naval intelligence sector. For many, he is the true academic heir of Haverfield (Hingley, 2000: 131). In Archaeology, Collingwood dedicated itself to study, mainly, the Roman 
settlements of Roman Britain and the "Romanisation", in publications like Roman Britain, The Archaeology of Roman Britain and Roman Britain and the English Settlements (the latter in partnership with J. N. L. Mires, but with separate contributions in the volume). From 1912, Collingwood actively participated with Haverfield in archaeological excavations of Roman sites in the north of England. Even though he would say that Archeology was just a hobby for him, Collingwood was in his time an authority also in this area of research, producing hundreds of works about Roman Britain and on what he judged to be the Roman cultural heritage left to England after the 5th century AD. Later, he would focus his attention on Philosophy and his lectures brought forth one of his posthumous works: The Idea of History. Published posthumously by his pupil T. M. Knox, the study became a reference for the Philosophy of History in the post-war period. During his trip to Asia, between 1938 and 1939, he began to write the work that he believed to be his greatest achievement: The Principles of History, only published much later, at the end of the 20th century. Upon his return to Oxford, Collingwood worried about the advance of Nazi and Fascist ideas and the political and moral effects of World War II, wrote The New Leviathan. At this moment of great worldwide instability, Collingwood assumes political views that differ from many of his Academy colleagues, who tended to be still prone to the survival of the European colonizing project. After his trip to the Dutch colonies in Asia, it seemed clear in his mind that Western neocolonization could also have harmful consequences for colonized countries (Collingwood, 1923: 14; Hingley, 2000: 131-2) and that the existing chasm between the rich and the poor was an offense to the ideal of civility that was sought. For Collingwood, the use of the strength of the richest to accumulate wealth in order to separate the rich and the poor was a symptom of the destruction of civilization or of barbarism (Collingwood, 1942: 38 e $74,82-83)^{2}$

It can be argued that it was the interpretation and the definition of what is the past by post-processual Archeology that brought Collingwood's approach back to the fore (Whitley, 1998a: 179; Renfrew, 2005b: xi; e 2005c: 41). Collingwood's emphasis on understanding the past through the thought rather than through empirical methods has made him a significant influence on the post-processual theoretical debate around how Archeology and History can work together in the cognitive interpretation of extinct societies (Whitley, 1998a:179-80). Although it is

\footnotetext{
2 The biographical information of R. Collingwood presented here was collected, except when other authors are cited, from the Stanford Encyclopedia of Philosophy website at the following link: http://plato.stanford.edu/entries/collingwood/. Accessed on $11 / 20 / 2017$.
} 
not possible to list here with all conviction what are, potentially, the multiple motivations for the resurgence of Collingwood's ideas in postmodern archaeological literature, in the context of an important segment of the discipline that adopts more subjective theories and methods for understanding the past, it is not hard to guess why Collingwood is seen as an iconic figure. Among the likely reasons for the renewed interest in studying his conceptions may be the fact that Ian Hodder, himself a symbol of the post-processual movement, had sought his own idealistic inspiration in the way Collingwood advocated that the past should be interpreted (Cobb, 1998: 201). There would not be a way to explore in depth Collingwood's theories on the interpretation of the past in this space, but I am now going to present some glances of his formulation.

\section{Collingwood's "empathy" and "renaissance"}

The most controversial point concerns the empathy between the mind of the researcher and that of the subject he studied through the excavated artifacts. Collingwood postulated that the historian would be able to recreate the past and share the same thinking of the individual being studied:

[T] he historian must reenact the past in his own mind...When a man thinks historically, he has before him certain documents or relics of the past. His business is to discover what the past was which has left these relics behind...This means discovering the thought ...expressed [by them]. To discover what this thought was, the historian must think it again himself (Collingwood, 1946: 282-3; emphasis on the original. Apud Whitley, 1998: 17980).

Therefore, Collingwood believed that the historical past should be rebuilt in the thought, in the present (Collingwood 1946: 293), mutatis mutandi, an idea also shared by many post-processual archaeologists (Shanks \& Tilley, 1992: 14-5 and Shanks \& Hodder, 1998: 78; Hills 2005: 140) and historians regarded as postmodern (Jenkins, 1991: 12), something that I will discuss below.

The investigator's presuppositions are also another area of postprocessual interest (Shanks \& Hodder, 1998: 82-3) which can be found in Collingwood. Collingwood argued that in one way or another every student of the past passes some judgment when approaching his or her object. In fact, without this prejudice there would be no History (Collingwood, 1999: 217), because it is precisely this historian's judgment 
that makes him or her select, among a myriad of things that have happened, his or her object of study. In Collingwood's conception, all historical research begins with prejudice (Idem: 213), which would be nothing more than "a desire to discover that a particular answer to a question made by someone is correct (Ibidem: 210)".

The phenomenon would be virtually inevitable:

Instead of hypocritically flattering ourselves that we have no prejudices, or vainly trying to rid ourselves of them, we ought to examine our own minds and find out what our prejudices are. We may be certain that they exist; very well, let us discover them and discipline ourselves to attend with special care to the evidence in favour of views against which we are prejudiced (Id.Ibidem: 212).

So, the reader could be aware of the prejudices that affect the investigator, who should not make them secret (Id.Ibidem: 213). ${ }^{3}$ For Collingwood, the historian must also concede that knowledge is the result of his questions to the object of study. Questioning is the soul of knowledge, whereas information is only its body. However, while the answers may change, as they are continually revised, the questions remain intact (Collingwood, 1924: 78 and 80). ${ }^{4}$

As it has already been mentioned, Collingwood is known for his proposal to study the thought, not the actions, and when making a clear distinction between Naturwissenschaften and Geisteswissenschaften, he argues that the role of history is not to study the human being in its nature, in other words, the "natural history", since the word "history" does not reflect our interest in the evolution of the homo sapiens, but rather in people as civilized beings. In Collingwood's, history must deal with the study of the mind, created and managed by rational processes:

(...) a great many things which deeply concern human beings are not, and never have been, traditionally included in the subject-matter of history. People are born, eat and breathe and sleep, and beget children and become ill and recover again, and die; and these things interest them, most of them at any rate, far more than art and science, industry and politics and war. Yet none of these things have been traditionally regarded as possessing historical interest. Most of them have given rise to institutions like dining and marrying and the various rituals that surround birth and death, sickness and recovery; and of these rituals and institutions people write histories; but the history of dining is not

\footnotetext{
${ }^{3}$ In an approach to modern literature, Shanks and Hodder also address the 'prejudices' of the 'interpreter' (archaeologist), even stating that, in addition to being beneficial, they are the appropriate way for achieving the 'real' and 'objective' understanding of what we are studying (Shanks \& Hodder, 1998: 82-3).

${ }^{4}$ There is also a curious modern parallel in the emphasis on the use of hermeneutics (in the form of questions and answers, broadly) in Shanks \& Hodder (1998: 83).
} 
the history of eating, and the history of death-rituals is not the history of death (Collingwood, 1999: 46).

Thus, the "animal man" does not interest History for it will seek to deal with the study of mind and sensibility, elements created by rational processes such as language and semantics, which create variant symbols to explain the world (Veyne, 1982: 12-3). This language was different from that of the present in the multiple sociocultural contexts of the past, making it (the past) a foreign territory (Jenkins 1991: 43).

Still:

(...) [the so-called Res Gestae] are not the actions, in the widest sense of that word, which are done by animals of the species called human; they are actions in another sense of the same word, equally familiar but narrower, actions done by reasonable agents in pursuit of ends determined by their reason (Collingwood, 1999: 46).

Collingwood points out that to understand the past historically, the historian will not formulate empirical hypotheses, rather he must, and can, reconstruct the thought of the individual from the past because the thought is a phenomenon that is not restricted to the agent at a given historical moment. The thought is, in principle, public and can be rediscovered ${ }^{5}$. This is how Collingwood explains how he approaches Plato's thinking, for example:

(...) in its immediacy, as an actual experience of his own, Plato's argument must undoubtedly have grown up out of a discussion of some sort, though I do not know what it was, and been closely connected to such a discussion. Yet if I not only read his argument but understand it, follow it in my own mind re-enacting it with and for myself, the process of argument which I go through is not a process resembling Plato's, it is actually Plato's so far as I understand him correctly (Collingwood, 1946: 301).

Thus, historical understanding occurs when the historian experiences the same thinking process through which the character he or she investigates passed (Renfrew, 2005: 41). The prestige that Collingwood acquired in the Philosophy of History would guarantee him in this field of knowledge an expected audience in the first half of the $20^{\text {th }}$ century and his works in Archeology would offer the possibility of applying the same theoretical premises to the studies of material culture. The unexpected, however, is his resurgence in the archaeological interpretive theories at the end of the same century. The receptivity and certain reverence for his ideas about the reconstruction of the past through the mind by some archaeologists

5 This proposition seems to be more conceptual than methodological in Collingwood's work. 
still cause some surprise. ${ }^{6}$ The polimathy of the works published by Collingwood throughout his life has spawned several connections between fields of knowledge today more demarcated between Philosophy, History and Archeology, in a largely feedback dynamic. The 1990s saw a new theoretical approach between History and Archeology and what happened later to such a reunion was the resurgence of some old historians and philosophers of History from the early $20^{\text {th }}$ century in the post-processual publications, as inspiration or parameter for the approach of societies of the past, especially those authors whose works supported more contextualized inferences and/or investigations aligned with the subjectivities involved in the reconstruction of the past; or those who had drawn and proclaimed the narrative nature of the document with the formula "questions-problems-anwers-solutions", such as the theories of the long durée of the Annales (Peebles, 1998: 189). It is in this scenario that the names of R. G. Collingwood, Braudel and Bloch reemerge in modern archaeological bibliographies (Funari, 1998b: 10; Whitley, 1998a: 179-80; Renfrew, 2005b: xi and 2005c: 41). It will be in the so-called Cognitive Archaeology that Collingwood's ideas are to find more acceptance. In this field, grosso modo, the archaeologist's effort is directed to finding the thought of the creators and users of the artifacts of the past, more specifically, in the reenacting of their meanings through the analysis of their symbologies, and in the proper questioning directed to them. Ultimately, there is a search for understanding the working of the minds behind the artifacts. Although the idealism of this "get-in-themind" is now inevitably met with great skepticism, the search for meanings is the great goal of interpretative (or post-processual) Archaeology that emerged in the late 1980s. It is in this theoreticalmethodological framework that the great parallels with the philosophicaltheoretical works of Collingwood's hermeneutics are observed (Renfrew \& Bahn, 2005c: 41; Wylie, 2005: 24b; see also Peebles, 1998). Not everything from Collingwood is reused in post-processualism, of course, and his own historical context matters. We speak here much more of resignifying concepts as any adoption of past or present theories passes through filters that surround the scholar (Jenkins, 1991: 19) and, thus, it is only reasonable to think that Collingwood's ideas were subjectively reconstructed by those who have been making use of them. For instance, it is useful to evaluate how colonialist discourses of the British Empire in that period affected the formation of Collingwood's ideas, his way of looking at the past, for example, and how some of his preconceptions

\footnotetext{
${ }^{6}$ However, this apparent "telepathic" capacity of the researcher is discredited by some (Jenkins, 1991: 39) or even ridiculed by others, especially, but not only, when suggested to Prehistory studies (Kohl, 1997: 17a, Gilman, 1987: 516; Renfrew, 2005b: 41-2).
} 
came to the post-processual debates. In a way, Collingwood's "rebirth" in archaeological theory was far more energetic than the survival of his field studies. However, his publications on Roman Britain and its "romanisation" have carried a weight that cannot be ignored. I will briefly discuss this matter below.

\section{The "Romanisation" of Roman Britain}

Ancient Rome's process of territorial and cultural expansion over the provinces, especially in the Principate, known in modern literature as "Romanisation" has been a long standing presence in the works of archaeologists and/or historians imbued with seeking explanations for the advance of the Roman Empire and, ultimately, of the assumed absorption of Roman culture and identity. Conventionally, according to more traditional approaches, the adoption of material culture implied as "Roman" would make it possible to measure how "romanised" the provinces were or not. The more intense the presence of "Roman" and "Romanised" artifacts became, the greater the cultural transformation, and also the identity transformation (Grahame, 1998: 175). Since the late 1980s, this linear connection between material culture and identity has not passed unscathed by the criticism of the post colonialist generation of researchers, and thus, many archaeologists and historians are reluctant to accept the immediate link between the presence of "Roman" material culture and any suggestion of Roman identity, or even any sign of low resistance to the conquerors (Grahame, 1998: 150 and 158; Siân Jones, 1997: 114-5 and 133-4; 1999: 220-1). The Oxford generation of archaeologists and historians of the beginning of the $20^{\text {th }}$ century that influenced Collingwood and his subsequent publications had a great impact in the development and the diffusion of the "Romanization" concept. Plotting its precise origins can be a chimera, but it can be argued that the more precise contours of the debate in the academic field can first be traced to Theodor Mommsen (1817-1903), a historian and law scholar who propagated the theory of Rome's "defensive imperialism". In 1854, Mommsen published a comprehensive work on the Roman Republic, and the parallel with the political situation of 1848 and with the unifications of Italy and Germany became noticeable. ${ }^{7}$ For him, certain Roman institutions, such as citizenship, Latin, coinage, etc., could be measured so that the intensity of the Roman culture's adoption by the provinces could be established (Freeman, 1997: 31). Mommsen managed to have his ideas

\footnotetext{
7 Freeman considers that Mommsen's work, Römische Geschichte (1854), can be compared to a political pamphlet (Freeman, 1997: 30).
} 
divulged at Oxford, inserted there by Henry Pelham (1846-1907). However, it was Francis Haverfield (1860-1919), the academic successor of Pelham's who eventually integrated studies on the "Romanisation" of Roman Britain with the rest of Europe, fostering a perception that there had been a homogeneous Roman Empire (Freeman, 1997: 37). Haverfield incorporated epigraphy and other archaeological data into the analysis of "Romanization" and, as Henry Pelham had done before him, sought in the Roman past certain practices that had parallels in their time. For Haverfield, "obsessed with the belief in the common descent of all European peoples, the archaeological record could show cultural hegemony throughout the Roman Empire" (Pinto, 2016: 62; see also Hingley, 1996: 39; 1997: 83).

Collingwood devised "Romanisation" as a process that took the Britons out of a wild, rustic wildlife, rescued from the savagery of human sacrifices and from the immersion into the marshy areas of the island. For him, the Romans dominated the island, imposed their rule and civilization, and when they left, in the early $5^{\text {th }}$ century AD, they left behind a land that was again given over to Celtic barbarism. Collingwood, however, tries to show that the Britons who were "left behind" were no longer those whom the Romans had encountered nearly four hundred years earlier. Those Britons were now "Romanized". Therefore, for Collingwood, there had been a clear cultural continuity between the Roman and the Anglo-Saxon periods, albeit partial (Collingwood, 1923: 11-2 and 97-8). The complex question of ethnicity and culture seems inescapable here. For Collingwood, the union of Roman and Celtic culture created another amalgamated harmonious culture. Something he understands was impossible in the case of the British and the Indians. According to Collingwood, these cultures will forever be separate, and can never generate a resulting culture (Collingwood, 1932: 144). In what can be seen as a reflection of his antiNazi and anti-fascist sentiment, Collingwood strove to show that the Celtic peoples of Roman Britain, even after centuries of "Romanisation," had nothing to do or showed no resemblance with the Italian or German physical characteristics (Collingwood, 1937: 185).

Over the last century, many scholars have been proposing alternative approaches to those of Haverfield and Collingwood's. ${ }^{8}$ Recently, the main

8In 1990, archaeologist Martin Millett published The Romanization of Britain, when he looked for a different view for what he considered to be a paternalistic approach to Roman Britain's studies, targeting Brittannia by SS Frere in 1967 and Roman Britain by Peter Salway (1984, first edition in 1981). Millett argued his study offered a distinct take on "Romanisation" when the Bristish Empire was no longer a reality, at least not 
criticisms arising from the archaeological literature are in the use of the nationalist political discourse that exists behind the term "Romanisation", comparing it to a contemporary imperialist ideal where most of the explanations about Roman imperialism would be overly anchored. Our ancient documentary sources would be interpreted in the bosom of an ideological baggage linked to the notions of the imperialism of the $20^{\text {th }}$ century. With increasing intensity, researchers from colonized countries have denounced this influence and carried out severe criticism of the dissemination of a sectarian political discourse marked by colonialism (Mattingly, 1997: 14-7; Siân Jones, 1997: 129-30; Hingley, 2000: xiv). In the 1990s, the concept of "Romanization" began to be studied as "acculturation"9, that is, a dialectical exchange that nevertheless only reflects a post colonialist approach to the same interpretative criteria of Francis Haverfield's studies. It is possible to see that complex concepts such as power, wealth, age, gender, ethnic identity, etc. are not contemplated in "Romanisation", making it an intrinsically exclusive and inadequate discoursive term. (Hingley, 1996: 44-5; 1997: 85). There is little doubt that Francis Haverfield was the great promoter of the RomanoBritish studies at the beginning of the $20^{\text {th }}$ century. But his concepts were, to a large extent, marginalized in the academy (Freeman 2007: 536). Collingwood's figure is a landmark in Romano-British research and his "Romanisation" and Haverfield's death in 1919 would have been the great factor that elevated Collingwood to a great eminence in studies of such kind. Collingwood was one of Haverfield's few students who survived the First World War and eventually assumed (not reluctantly, it must be said) the responsibility of continuing the Roman Inscriptions of Britain (RIB) project (Collingwood \& Wright, 1965). Haverfield intended to make

so much so as when Frere and Salway had developed their main researches (Millett, 1990: xv-xvi). Salway, who is an historian, had written Roman Britain to replace Roman Britain and The English Settlements, of Collingwood and Myres (1937).

9 One of the first scholars to define "Acculturation" was Melville J. Herskovits (18951963), professor of Anthropology at Northwestern University and founder of the first African studies program in the United States. His works help to break the racist thoughts dictated by many European and American intellectuals until World War II. In his work The Myth of the Negro Past (1941), acculturation was defined, in generic terms, as "studies of those phenomena that arise when groups of people with different cultures come into continuous contact for the first time, with subsequent changes in cultural patterns of one or both groups (Herskovits, 1941: 10)". Despite the readiness to point to a possibility of mutual cultural change, the use of the term in Anthropology and in other Human Sciences indicates that there is a marked tendency to emphasize the unidirectional influence of the phenomenon. Thus, acculturation has been associated with the idea that one superior higher culture would dominate another, inferior. Scenarios for such analyses are prejudiced in favour of the Roman dominion over the western provinces and the West's impact on the so-called Third World nations (Miller, 1997: 244). This note, in its entirety, can be found in Pinto, 2016: 103, n. 44. 
an epigraphic compendium of Britain that could overcome the flaws he saw in the seventh edition of another vast corpus of Latin epigraphic inscriptions, initiated and developed by Mommsen in the 19th century: the Corpus Inscriptionum Latinarum (CIL) (Freeman, 2007: 539). Despite assuming Haverfield's position in the project, Collingwood seemed to prefer to be seen much more as a philosopher and historian than as an archaeologist. During the early years of his production, from 1912 to 1925, Collingwood focused his attention almost exclusively on Archeology and it was only between 1925 and 1933 that his gaze began to turn to the Philosophy of History, while Archeology went through certain negligence. From 1933 on, Collingwood's publications take an almost purely philosophical course (Freeman, 2007: 537-540), but his appreciation for Philosophy was already demonstrated in his first archaeological works. In fact, Collingwood frequently criticized Haverfield for neglecting philosophy in his archaeological researches (Freeman, 2007: 543). However, this was not the only criticism Collingwood made to Haverfield. In a review of Haverfield's The Roman Occupation of Britain (1924), Collingwood expressed his conclusions about the scope of "Romanisation":

Haverfield was led to exaggerate both the degree and the extent of this Romanization: to understate the degree to which Romano-British culture, even where it was most Roman, remained British, and to overstate the extent to which it affected the poorer classes of the population. At one end of the scale, the village-dwellers in all parts of the country parts of the country were affected indeed, but not very deeply affected, by Roman civilization; and the habits of life which they reveal always continued to show profoundly unRoman elements. Haverfield was not in fact blind to this; on the contrary, he often called attention to it; but often, for the sake of making a legitimate and important point, he understated it, and left an impression of seeing nothing in Romano-British culture except the Roman element (1924a: 436. Apud Freeman, 2007: 544).

In a form of distancing from the main argument of his former tutor, Collingwood reinforced the need to recognize the enormous oscillation and discrepancy in the distribution of "romanisation" on the island, in contrast to what he perceived to be a homogenization made by Haverfield. As for the way in which Haverfield could sometimes overestimate his interpretations, it is ironic that this is precisely the same and greater criticism that Collingwood's own publications would later receive (Freeman, 2007: 544).

In 1923, Collingwood published his first major work about Roman Britain, Roman Britain. The volume won a second edition in 1932, and yet another revision in 1949. The publication expressed Collingwood's 
position on "Romanisation", partly influenced by Haverfield's oeuvre, but it was not specifically critical of them. While a first edition, emphasizing how a Romano-British culture fused satisfactorily, a second edition pointed to flaws in this cultural syncretism (Freeman, 2007: 546). The book was also praised for using a language much more accessible to the non-specialized reader (Johnston, 1967: 39). What is clear in the work, especially in the reviews, is that Collingwood no longer believed in the possibility of measuring the "Romanisation" of Roman Britain:

We cannot be content simply to assert that Britain was Romanized. The civilization which we have found existing in the towns, the villas, and the villages is by no means a pure, or even approximately pure, Roman civilization bodily taken over by the conquered race ...In a sense it might be said that the civilization of Roman Britain is neither Roman nor British but Romano-British, a fusion of the two things into a single thing different from either. But this is not a quite satisfactory way of putting it; for it suggests that there was a definite blend of Roman and British elements, producing a civilization that was consistent and homogeneous throughout the fabric of society. The fact is rather that a scale of Romanization can be recognized. At one end of the scale come the upper classes of society and the towns; at the other end, the lower classes and the country. The British aristocracy were quick to adopt Roman fashions, but the Roman fashions which they adopted were rather those of Roman Gaul than those of Rome itself, so that their borrowings are already Romano-Celtic rather than Roman. But this Romano-Celtic civilization gradually becomes less Roman and more Celtic as we move from the largest towns and largest villas to the small towns, the small villa of humbler landowners, and lastly to the villages. Here we encounter a stratum of the population in whose life the Roman element hardly appears at all; if we must call their civilization RomanoCeltic, it is only about five per cent Roman to ninety-five Celtic (Collingwood, 1949: 91 and 92).

It is well discernible in the study a concern on the part of Collingwood to connect and to insert the studies of Roman Britain to and into the broader British history. In order to do so, he will pay great attention to the Roman process of leaving the island. In the 1949 edition of Roman Britain, a supposed "downfall" of Roman culture owes much more to its "thin veneer" nature than to the barbarian invasions. The Roman presence itself on the island is no longer a fortuitous event, and will present its own internal logic (Collingwood, 1949: 12-3).

In 1930, Collingwood published The Archaeology of Roman Britain. For some, this was to become Collingwood's most influential work in Archaeology, only compared to his great success in the field of Philosophy of History: The Idea of History (1946). The volume sought to approach Britain's "Romanisation" in a more technical way, without using historical texts, in an attempt to synthesize the last fifty years of 
Romano-British investigations. It was a response to the growing professionalization of Roman Britain studies and it was generally very well received by his peers (Freeman, 2007: 548).

The last of Collingwood's works around Romano-British research was published in 1936 and reedited in 1937, titled Roman Britain and the English Settlements, in partnership with J.N.L. Myres. It is considered as the first study to offer a complete narrative of the four centuries of Roman occupation in Britain, and was met with mixed reviews. Evaluated by many as a work that only added updates to the data previously collected by Haverfield, Roman Britain and the English Settlements was also accused of being a mere vehicle to Collingwood's philosophical theories (Freeman, 2007: 550-1). Here again, "Romanization" is conceived as a dynamic process, not linearly happening. Even so, Collingwood assumes that the whole Roman Empire would have gone through the same type of political-cultural approach, in something that was configured as a logical intentionality and uniform consensus. In this, Collingwood considered to be the greatest difference between the Roman Empire and the reality of the British Empire of his time, especially in India and in Africa. Collingwood acknowledged that comparisons were frequent between the two empires, but was opposed to such approximations. For him, the Roman Empire had been unique. What draws our attention to the question of the uses of the past and to the comparisons between Rome and the British imperialism is Collingwood's criticism of the work of a contemporary colleague, the influential British writer Rudyard Kipling (1865-1936). According to A.R. Burn

\footnotetext{
Collingwood, following Haverfield, was fond of emphasising the thorough Romanization of the Roman Empire which made Roman Gaul or Roman Britain very different from British colonial India or Africa. He was particularly hard on Kipling, for pictures in Puck of Pook's Hill on Roman Britain conceived on British India lines, with a sharp line between Roman and 'natives'. In this he was clearly right. With all their faults, the Romans never drew any such line (1932: 66. Apud Freeman, 2007: 550).
}

According to Parker (2000), Collingwood applied his philosophy of history in the interpretation of the material vestiges he analysed. It was all about his way of dealing with the interpretation of the past by recreating the events of the past in his own mind, the empathy with the historical person, not through the presumption of how he or she thought, but rather in the full understanding of his object and of his or her thinking (Parker, 2000: 166). For Collingwood, every idea (or question and answer), is formulated in response to a specific problem. For Freeman (2007), the consequences of this thinking in the field of Archeology is that "every object found in a site must have served a 
function or purpose in the life of its user and/or inhabitant of the site (p. 555)." In fact, in his time, Collingwood was heavily criticized for having, according to some, manipulated archaeological data to suit his solutions (idem). Today, however, the rigidity of the identitary concepts presented by Collingwood in Roman Britain and the English Settlements turned out to be his most harshly criticized aspect. Terms such as "Celtic", or "Roman", or "Romano-British" appear in the work as elements devoid of internal tensions, such as monoliths. Collingwood recognized the limits of "Romanisation," but didn't go so far as to question its inconsistent and multiple meanings, neither its conceptual precariousness (Freeman, 2007: 553).

\section{Conclusion}

In the most accepted view of the academic Roman Britain "dynasty", Collingwood's death in 1943 transformed Ian Archibald Richmond (19021965) into his successor and a new research leader. His work has been acknowledged as that of a great archaeologist and historian, in a line of succession that begins in Haverfield and passes through Collingwood (Birley, 1966: 302). It should be noted that this line emphasizes the Oxford tradition where, furthermore, Richmond's thinking continues to exert a great influence on his students. In fact, according to some, more than his work, his greatest achievement was the creation of a solid group of students who came to occupy major positions in the British academic centres, something that Collingwood ultimately was not able to achieve (Freeman, 2007: 557, 564-5).

It is true that nowadays Collingwood is much remembered for his work in the Philosophy of History, but it was from his work in Archeology that he withdrew his best case studies (Hodder, 1986: 90-102). Even though Collingwood had later lessened his attention to Archaeology, he would never fully underestimate his own contribution to the Romano-British studies. Especially his dedication to the RIB project, despite any dissatisfaction he could demonstrate with some of its reception and results. In what can only be seen as positive, his interests in Roman Britain were much more in rural and underprivileged populations rather than in the military camps, somewhat opposed to what Haverfield had done previously (Freeman, 2007: 545). In the interpretive field, his philosophical gaze was sometimes allied to his precise descriptions and proposals for more polysemic interpretations (Richmond, 1943b: 254, contra Freeman, 2007: 556). Some of his interpretive models of uillae organizations remain in use to this day (Hingley, 2010: 61). This "colorful" 
interpretive framework and his hybrid academic position - because he was a philosopher, historian, and archaeologist - gained him harsh criticism that today deserve some form of revision. Considered by some, nowadays, as a "problem" to the studies of Roman Britain, given his academic greatness at the time and his stifling publications, according to Freeman (2007: 557-8), Collingwood seems to suffer much more from an extemporaneous evaluation of his temper rather than of his contributions. If he tried to answer his pre-established questions at the excavated sites, and let some facts escape, as his critics point out, it seems to be a situation much closer to the reality of other archaeologists of his (or our) time than is perceived (for a more appreciative view of Collingwood's ouevre than that expressed by Freeman (2007), see Leach, 2009). There is a great deal of consistency in his way of assessing the historian's prejudice when approaching his/her objects and the way Collingwood dealt with his own archaeological sources. This is insufficiently explored by his critics, I think. His resurgence in post-processual Archaeology may sometimes be ridiculed, but his dedication to the Romano-British theme, and the fact that he was virtually the only scholar to address this question at his time, with many excavations and publications in this area, cannot fail to make an impact and gain him due recognition.

\section{Acknowledgement}

I am very grateful to Glaydson José da Silva, who organized this dossier, for the invitation to contribute in this homage to Professor Pedro Paulo Funari. I would also like to congratulate all the people involved in this project. The author is the sole responsible for any errors or omissions in this paper. This English version of this paper was made by Larissa Moreira Alves, with some minor occasional changes by me. The text in Portuguese should prevail to claim or correct any possible inconsistencies.

\section{Bibliography}

BIRLEY, E. "Sir Ian Archibald Richmond 1902-1965". Proceedings of the British Academy 52, 1966, p. 293-302.

BURN, A. R. The Romans in Britain, an Anthology of Inscriptions. Londres: B. Blackwell, 1932. 2a. edição de 1969. 
CHIPPINDALE, C. "Ambition, deference, discrepancy, consumption: the intellectual background to a post-processual archaeology". In: YOFFEE, N.; SHERRATT, A. (Org.) Archaeological theory: who sets the agenda? Cambridge: CUP, 1997, p. 27-36.

COBB, C. R. "Social Reproduction and the Long Durée in the Prehistory of the Midcontinental United States". In: Whitley, D.S. 1998. 199-216.

COLLINGWOOD, R. G. "Review of Haverfield 1924". Antiquaries Journal 4. 1924a, p. 435-7.

COLLINGWOOD, R. G. Roman Britain. Londres: OUP, 1923.

COLLINGWOOD, R. G. Roman Britain. Oxford: Clarendon Press, 1949.

COLLINGWOOD, R. G. The Archaeology of Roman Britain. Londres: Methuen, 1930.

COLLINGWOOD, R. G. The Idea of History. Oxford: Clarendon Press; Oxford: OUP, 1946. Edição de 1993.

COLLINGWOOD, R. G. The Principles of History. Oxford: OUP, 1999.

COLLINGWOOD, R. G.; MYRES, J.N.L. Roman Britain and the English Settlements, Oxford: Clarendon Press. Segunda edição, 1937.

COLLINGWOOD, R. G.; MYRES, J.N.L. Roman Britain and the English Settlements, Oxford: Clarendon Press. Segunda edição, 1937.

COLLINGWOOD, R. G.; WRIGHT, R. P. The Roman Inscriptions of Britain, vol. I. Oxford: OUP, 1965.

COLLINGWOOD, R.G. Speculum Mentis. Oxford: Clarendon Press, 1924b. COLLINGWOOD, R.G. The New Leviathan. Oxford: Clarendon Press, 1942. Edição de 1992.

COLLINGWOOD, R.G.; MYRES, J.N.L. Roman Britain and the English Settlements, Oxford: Clarendon Press. Segunda edição, 1937.

FREEMAN, P. W. M. (1997) "Mommsen to Haverfield: the origins of studies of Romanization in late 19th-c. Britain". In: MATTINGLY, D. J. ed., 1997. 27-50.

FREEMAN, P. W. M. The Best Training-Ground for Archaeologists - Francis Haverfield and the Invention of Romano-British Archaeology. Oxford: Oxbow Books, 2007. 
FUNARI, P. P. A. (1998) “Arqueologia, História e Arqueologia Histórica no Contexto Sul-Americano". In: Funari, P.P.A. org. (1998) Cultura Material e Arqueologia Histórica. Campinas: Coleção Idéias, 1998, p. 7-34.

FUNARI, P. P. A. "Bretanha Romana". Revista de Historia da Arte e Arqueologia 1. Campinas: UNICAMP, 1994, p. 249-52.

FUNARI, P. P. A. "Dressel 20 amphora inscriptions found at Vindolanda: the reading of the unpublished evidence." V.A. Maxfield; M. J. Dobson (Org.) Roman Frontier Studies 1989. Exeter: University of Exeter Press, 1991, p. 65-72.

GILMAN, A. "Resposta a T. K. Earle e R. W. Preucel". In: "Processual Archaeology and the Radical Critique". Current Anthropology 28(4), 1987, 516.

GRAHAME, M. "Material culture and Roman identity: the spatial layout of Pompeian houses and the problem of ethnicity". In: LAURENCE, R. e J. Berry (Org.) Cultural Identity in the Roman Empire, Londres: Routledge, 1998, 156-78.

HERSKOVITS, M. J. The Myth of the Negro Past. Nova Iorque: Harper \& Brothers Publishers, 1941.

HILLS, C. "Historical Archaeology and Text" In: RENFREW, C.; BAHN, P. (Org.) Archaeology: The Key Concepts. Oxon: Routledge, 2005a, p. 137-41.

HINGLEY, R. “O Campo na Bretanha Romana: o significado das formas de assentamento rural".In: HINGLEY, Richard. O Imperialismo Romano: Novas perspectivas a partir da Bretanha. Trad. de Luciano César Garcia Pinto. Organização de Renata Senna Garraffoni, Pedro Paulo A. Funari e Renato Pinto. São Paulo: Annablume, 2010, p. 49-66.

HINGLEY, R. "Resistance and domination: social change in Roman Britain". In: MATTINGLY, D.J. (Org.) Dialogues in Roman Imperialism. Power, discourse and discrepant experience in the Roman Empire. JRS (suplemento 23), Portsmouth: RI, 1997a, p. 81-100.

HINGLEY, R. "The 'legacy' of Rome: the rise, decline, and fall of the theory of Romanization". In: Jane Webster e Nicholas J. Cooper (Org.) Roman Imperialism: Post-Colonial Perspectives. Leicester: Leicester Archaeology Monographs 3, 1996, p. 35-48.

HINGLEY, R. Roman Officers and English Gentlemen. The Imperial Origins of Roman Archaeology. Londres: Routledge, 2000. 
HODDER, I. Reading the Past: Current Approaches to Interpretation in Archaeology. Cambridge: CUP, 1986.

JENKINS, K. Re-thinking History, Londres: Routledge, 1991.

JOHNSTON, W. M. The Formative Years of R. G. Collingwood. The Hague Martinus Nijhoff, 1967.

JONES, S. "Historical categories and the praxis of identity: the interpretation of ethnicity in historical archaeology". In: FUNARI, P. P. A.; M. Hall, Siân Jones (Org.) Historical Archaeology: Back from the Edge. Londres: Routledge, 1999, p; 219-32.

JONES, S. The Archaeology of Ethnicity: Constructing identities in the past and present. Londres: Routledge, 1997.

KOHL, P. L. "Limits to a post-processual archaeology (or, The dangers of a new scholasticism)". In: YOFFEE, N.; SHERRATT, A. (Org.) Archaeological theory: who sets the agenda? Cambridge: CUP, 1997, p. 13-9.

LEACH, S. "An appreciation of R. G. Collingwood as an Archaeologist". Bulletin of the History of Archaeology 19(1), maio de 2009.

MATTINGLY, D. J. Dialogues of power and experience in the Roman Empire". In: Mattingly D. J, 1997b, p. 7-24.

MATTINGLY, D.J. (Org.) Dialogues in Roman Imperialism. Power, discourse and discrepant experience in the Roman Empire. JRS (suplemento 23), Portsmouth: RI, 1997a.

MILLER, M.C. Athens and Persia in the Fifth Century BC: A Study in Cultural Receptivity. Cambridge: CUP, 1997.

MILLETT, M. The Romanization of Britain: An essay in Archaeological Interpretation. Cambridge: CUP, 1992.

PARKER C. The English Idea of History from Coleridge to Collingwood. Ashgate: Aldershot and Brookfield, VT, 2000.

PEEBLES, C. S. Annalistes, Hermeneutics and Positivists. In: Whitley, D.S. (1998). 2005, p. 183-97.

PINTO, R. Duas Rainhas, um Príncipe e um Eunuco: masculino e feminino nos estudos sobre a Bretanha Romana. São Paulo: Annablume, 2016. 
RENFREW, C. "Cognitive Archaeology." In: RENFREW, C.; BAHN, P. (Org.) Archaeology: The Key Concepts. Oxon: Routledge, 2005a, p. 41-5.

RENFREW, C.; BAHN, P. (Org.) Archaeology: The Key Concepts. Oxon: Routledge, 2005a.

RENFREW, C.; BAHN, P. “Introduction." In: Renfrew \& Bahn, 2005b, p. xi-xiv.

RICHMOND, I. A. "Robin George Collingwood". Archeology Aeliana 4 XIX. 1943, p. 254-5.

RIDLEY, Aaron. R. G. Collingwood: uma Filosofia da Arte. São Paulo: Editora UNESP. Trad. de José Oscar da Almeida Marques, 2001.

SALWAY, P. Roman Britain. Oxford: OUP, 1984.

SHANKS, M.; HODDER, I. "Processual, postprocessual and interpretive archaeologies". In: Whitley, D.S. (1998), 1988, p. 69-95.

SHANKS, M.; TILLEY, C. Re-Constructing Archaeology. Londres: Routledge. $2^{\mathrm{a}}$ ed, 1992.

VEYNE, P. Como se Escreve a História. Brasília: Ed. UnB, 1982.

WHITLEY, D. S. "New Approaches to Old Problems: Archaeology in Search of an Ever Elusive Past". In: Whitley D. S. 1998b, p. 1-28.

WHITLEY, D.S. (Org.) Reader in Archaeological Theory: Post-Processual and Cognitive Approaches. Londres: Routledge, 1998a.

WYLIE, A. "A proliferation of new archaeologies: 'Beyond objectivism and relativism'". In: YOFFEE, N.; SHERRATT, A. (Org.) Archaeological theory: who sets the agenda? Cambridge: CUP. 1997, p. 20-6.

YOFFEE, N.; SHERRATT, A. (Org.) Archaeological theory: who sets the agenda? Cambridge: CUP. 1997. 